\title{
Tanaman Berkhasiat untuk Pengobatan Malaria di Indonesia Berdasarkan
} Etnofarmasi

\author{
Farah Mufidah $^{1 *}$, Ade Zuhrotun ${ }^{2}$ \\ ${ }^{1}$ Program Studi Sarjana Farmasi, Fakultas Farmasi, Universitas Padjadjaran \\ Sumedang, Jawa Barat, Indonesia \\ ${ }^{2}$ Departemen Biologi Farmasi, Fakultas Farmasi, Universitas Padjadjaran \\ Sumedang, Jawa Barat, Indonesia \\ *Email Korespondensi : farah17008@mail.unpad.ac.id
}

\begin{abstract}
ABSTRAK
Malaria merupakan penyakit yang umum terjadi pada negara-negara tropis termasuk Indonesia. Penyakit malaria disebabkan oleh Plasmodium sp. yang ditandai dengan beberapa gejala seperti demam dan nyeri sendi. Hal ini dapat dipengaruhi oleh berbagai faktor yaitu sanitasi yang buruk, migrasi, tingkat kepadatan penduduk, faktor pekerjaan, dan resistensi Plasmodium sp. terhadap obat-obat. Pengobatan konvensional malaria saat ini yaitu Chloroquine (Chloroquine Phosphate $\AA$ ), Mefloquine (Lariam $\AA$ ), Quinine (Quinine $\AA$ ), Primaquine (Primakuin $\AA$ ), Pyrimethamine (Pirimetamin $\AA$ ). Namun, beberapa etnik masyarakat wilayah di Indonesia masih mengkonsumsi tanaman herbal yang sudah ada dan didapatkan secara turun temurun. Dari 44 tanaman pengobatan malaria berdasarkan etnofarmasi diketahui tanaman terbaik yaitu Caesalpinia crista (L.) dengan nilai $\mathrm{IC}_{50}$ 0,09 $\mu \mathrm{g} / \mathrm{mL}$ dan tanaman dengan efektifitas terbaik yaitu Tithonia diversifolia (Hemsl.) dengan nilai $\mathrm{ED}_{50} 200 \mathrm{mg} / \mathrm{Kg}$. Adanya kandungan diterpen dan seskuiterpen pada bagian tanaman tersebut memberikan ekstrak memiliki aktivitas antimalaria yang baik.
\end{abstract}

Kata kunci: Malaria; Etnofarmasi; Plasmodium; $\mathrm{IC}_{50} ; \mathrm{ED}_{50}$

\section{Medicinal Plants For Malaria Treatment In Indonesia Based On Ethnopharmacy}

\begin{abstract}
Malaria is a common disease in tropical countries, including Indonesia. The presence of diseases caused by Plasmodium sp. can be influenced by various factors, such as poor sanitation, migration, population density, occupational factors, and parasitic resistance to drugs. Current malaria treatments are Chloroquine (Chloroquine Phosphate $(\mathbb{B})$, Mefloquine (Lariam $\AA), \quad$ Quinine (Quinine $\AA), \quad$ Primaquine (Primakuin $\AA$ ), Pyrimethamine (Pirimetamin $(\mathbb{B})$. However, the resistance against Plasmodium is a problem, so some people in Indonesia still consume herbal plants that have been there and obtained from generation to generation. From 44 malaria treatment plants based on ethnopharmacy, the best plant in malaria treatment is Caesalpinia crista (L.) with an $I_{50}$ value of $0.09 \mu \mathrm{g} / \mathrm{mL}$ and the plant with the best effectiveness is Tithonia diversifolia (Hemsl.) with an $E D_{50}$ value of $200 \mathrm{mg} / \mathrm{Kg}$.
\end{abstract}


The existence of diterpene and sesquiterpene in the plant parts gives a good antimalarial activity.

Keywords: Malaria; Ethnopharmacy; Plasmodium; $I C_{50} ; E D_{50}$.

\section{PENDAHULUAN}

Malaria merupakan masalah kesehatan utama yang paling umum terjadi di Negara tropis dan berkembang di Afrika sub-sahara, Asia Tenggara termasuk India. Gejala yang timbul pada penderita penyakit malaria yaitu demam tinggi, berkeringat banyak, nyeri kepala, pendarahan, mual, muntah, diare, pegal-pegal, dan nyeri otot (Asmara, 2018). Malaria adalah penyakit infeksi protozoa yang disebabkan oleh genus Plasmodium sp. Jenis malaria di Indonesia berdasarkan penyebabnya, yaitu Malaria Falsiparum disebabkan oleh Plasmodium falciparum, Malaria Vivaks disebabkan oleh Plasmodium vivax, Malaria Ovale disebabkan oleh Plasmodium ovale, Malaria Malariae disebabkan oleh Plasmodium malariae, dan Malaria Knowlesi disebabkan oleh Plasmodium knowlesi (Kemenkes RI, 2016).

Malaria telah menyerang 209 negara di dunia. Di Indonesia, malaria merupakan salah satu penyakit dengan prevalensi tinggi terutama pada wilayah bagian timur Indonesia (WHO, 2018). Skor Annual Parasite Incidence (API) menunjukan angka sakit (berdasarkan hasil pemeriksaan laboratorium) per 1000 penduduk dalam 1 tahun. Skor API tahun 2015 menunjukan 31,29 pada Papua Barat, dan 7,04 pada NTT dan angka tertinggi 31,93 terjadi pada wilayah Papua (Kemenkes RI, 2016).

Kasus malaria yang terdapat di Indonesia dipengaruhi oleh berbagai faktor yaitu sanitasi yang buruk, migrasi, tingkat kepadatan penduduk, faktor pekerjaan, dan resistensi. Resistensi yang terjadi terhadap Plasmodium falciparum dapat mengakibatkan kegagalan pada terapi sehingga berdampak pada kematian (Tripathi, 2013).

Strategi pengobatan malaria bertujuan untuk menghentikan pendarahan, menyembuhkan gejala klinis, membersihkan hipnozoit dari hati, mencegah kekambuhan dan untuk mencegah penyebaran infeksi (Kemenkes RI, 2016). Berbagai pilihan farmakologis yang tersedia untuk tujuan ini adalah Chloroquine (Chloroquine Phosphate $\AA)$, Mefloquine $\quad($ Lariam $\AA)$, Quinine (Quinine ${ }^{\circledR}$ ), $\quad$ Primaquine (Primakuin ${ }^{\circledR}$ ), $\quad$ Pyrimethamine (Pirimetamin $\left.{ }^{\circledR}\right) \quad$ (WHO, 2010). Namun, beberapa etnik masyarakat wilayah di Indonesia masih mengkonsumsi tanaman herbal yang dimilikinya.

Setiap etnik dari masyarakat Indonesia memiliki beragam kearifan, pengetahuan, dan pengalaman yang sangat penting bagi manusia dalam masyarakat modern. Interaksi antara manusia dan penyakit untuk waktu yang lama telah mendorong orang untuk membangun konsep yang berkaitan dengan penyakit dan cara-cara untuk mencegah dan mengobatinya (Heinrich, 2005).

Gabungan disiplin ilmu yang mempelajari tentang hubungan antara kebiasaan etnik dalam suatu kelompok masyarakat disebut Etnofarmasi. Etnofarmasi, ilmu yang mencakup farmakognosi, farmasetik (terutama yang berkaitan dengan sediaan galenik), pemberian obat, toksikologi, bioavailabilitas, metabolisme, serta farmasi praktis atau farmasi klinis (Ningsih, 2016).

Review artikel ini bertujuan untuk memberikan informasi kumpulan tanaman. pengobatan malaria berdasarkan etnofarmasi di Indonesia. Hasil yang disimpulkan berupa nilai $\mathrm{IC}_{50}$ dan $\mathrm{ED}_{50}$ dari tanaman terbaik.

\section{METODE PENELITIAN}

Artikel review disusun dengan menggunakan teknik studi literatur dalam bentuk data primer berupa jurnal nasional dan jurnal internasional dengan teori 
pendukung dari situs resmi seperti WHO dan Kementrian Kesehatan Republik Indonesia. Kriteria inklusi yaitu jurnal primer yang menjelaskan tumbuhan etnofarmasi dan kandungan kimianya dalam pengobatan penyakit malaria. Semua pencarian literatur menggunakan media online, seperti google scholar, NCBI, dan ScienceDirect dengan kata kunci "Etnofarmasi obat malaria", "Ethnopharmacy antimalarial", "Malaria", "Malaria traditional medicine by ethnic people" dan "Studies on Chemical Constituents [Nama tanaman]" hasilnya 70 jurnal, 2 buku, 2 website resmi.

\section{HASIL DAN PEMBAHASAN}

Tanaman-tanaman pada review ini diperoleh dari berbagai sumber data kemudian disusun berdasarkan Nama Lokal, Etnis, Nama Latin, Famili, Bagian Tanaman yang digunakan, Cara penyiapan, Kandungan kimia, Dosis, dan Pustaka. Hasil tersebut dicantumkan pada Tabel 1.

Berdasarkan hasil yang diperoleh, didapatkan 44 tanaman antimalaria dari berbagai suku di Indonesia, diantaranya terdapat Suku Anak Dalam, Suku Banggai, Suku Dayak, Suku Muna, Buton, dan Suku Tetun. Suku-suku tersebut memiliki praktek pengobatan tradisional yang telah ada sejak lama, secara lisan diturunkan dari satu generasi ke generasi berikutnya dengan tanaman-tanaman yang mereka temukan di Lingkungan tempat tinggal mereka. Pemrosesan tanaman yang digunakan sebagai obat dilakukan dengan proses dekoktasi yaitu merebus bagian tanaman utuh atau dihancurkan terlebih dahulu kemudian airnya diminum rutin setiap harinya. Pemrosesan lainnya dilakukan dengan direbus bagian tanaman kemudian airnya digunakan untuk berendam, kemudian uapnya dihirup. Bagian yang dapat diolah yaitu akar, batang, dan daun. Tanaman tersebut biasa juga dikombinasikan dengan tanaman anti malaria yang lain. (Taek et al., 2019).

Tanaman yang paling banyak digunakan yaitu Calotropis gigantean, Physalis angulata, Alstonia spectabilis, Carica papaya, Alstonia scholaris, Lansium domesticum, dan Curcuma domestica telah dikenal memiliki satu atau lebih dari aktivitas seperti antipiretik (Bose et al., 2010) dan analgesik (Murningsih et al., 2005). Beberapa tanaman yang rasanya pahit seperti Melia azedarach, Momordica sp. dan Alstonia scholaris untuk mencegah (Rinidar, et al., 2013) malaria juga memiliki aktivitas farmakologis sebagai stimulasi sistem imun (Dey, 2011).

Sebagian besar dari tanaman-tanaman (Tabel 1) sudah dilakukan penelitian terkait dengan aktivitas antimalaria secara In vitro dan in vivo. Secara In vitro, aktivitas antimalaria ditentukan berdasarkan Inhibitory Concentration ( $\mathrm{IC}_{50}$ dan $\mathrm{LC}_{50}$ ) yaitu konsentrasi dari senyawa yang menghasilkan penghambatan $50 \%$ pada Plasmodium sp., semakin kecil nilai $\mathrm{IC}_{50}$ maka semakin besar efektivitas penghambatan ekstrak terhadap pertumbuhan Plasmodium (Rinidar, et al., 2013). Dari 29 tanaman yang telah diuji secara In vitro terlihat tanaman yang memiliki nilai $\mathrm{IC}_{50}$ terkecil yaitu Caesalpinia crista (L.), $\mathrm{IC}_{50} 0,09 \mu \mathrm{g} / \mathrm{mL}$, lebih rendah dibandingkan nilai $\mathrm{IC}_{50}$ antimalaria klorokuin yakni $0,2 \mu \mathrm{g} / \mathrm{mL}$. Nilai $\mathrm{IC}_{50}$ mengarah pada korelasi antara struktur dan aktivitas. Pada struktur diterpen, kehadiran gugus asetoksil pada C-1 dan gugus hidroksil pada C-7 memainkan peran paling penting untuk aktivitas antimalarial (Kalauni et al., 2006). 


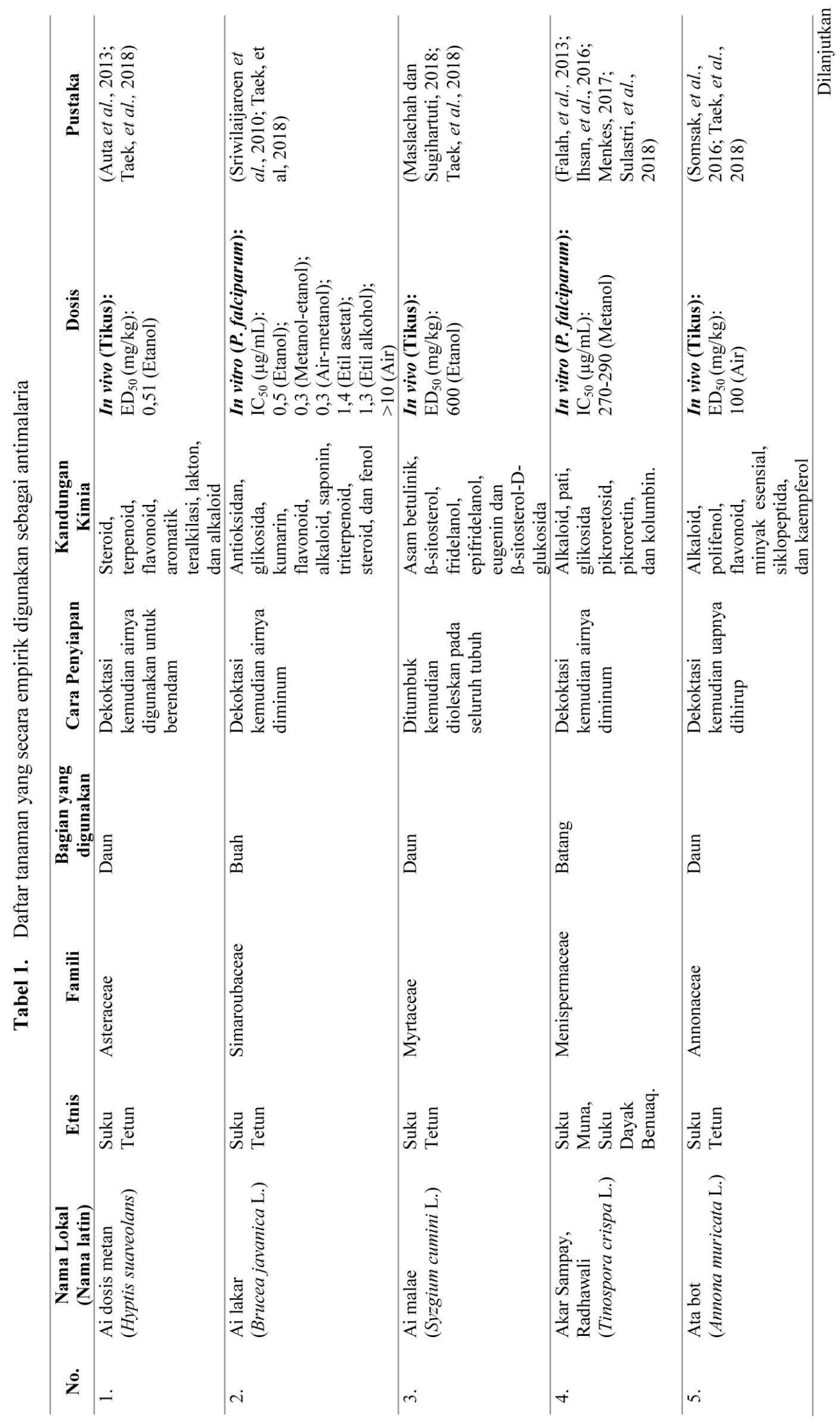


Tanaman Berkhasiat ... (Farah M., et al.)

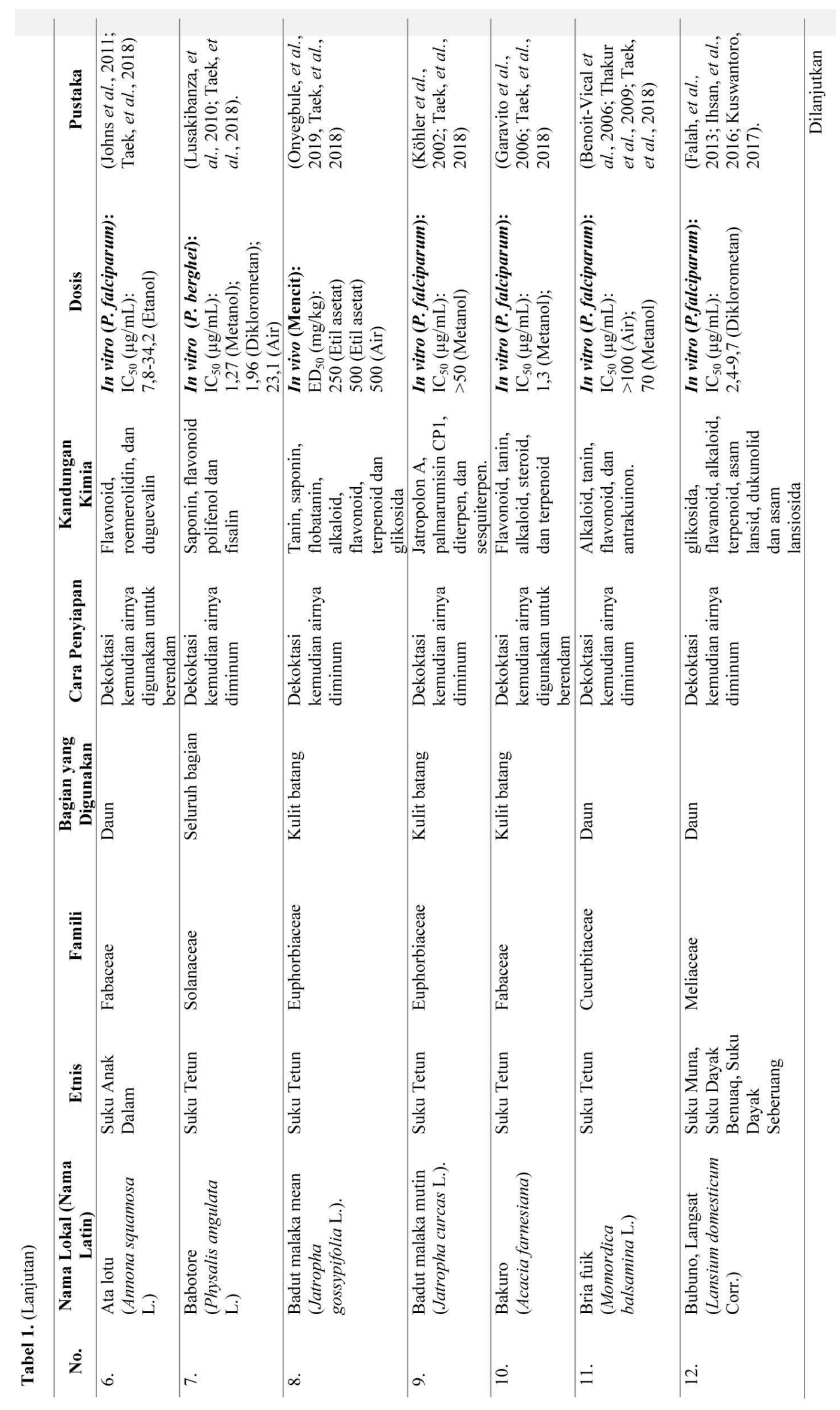




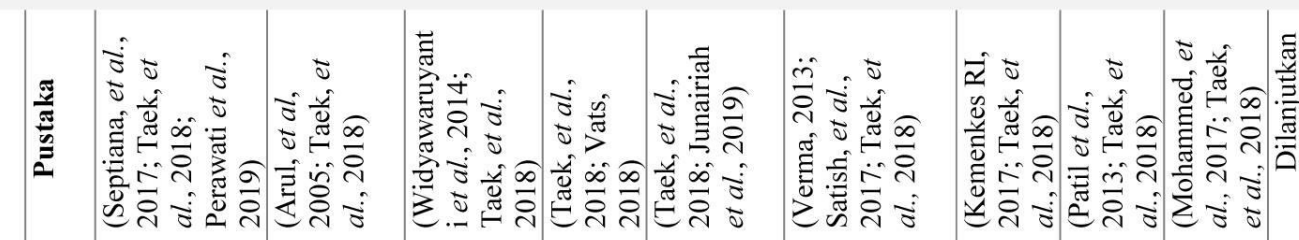

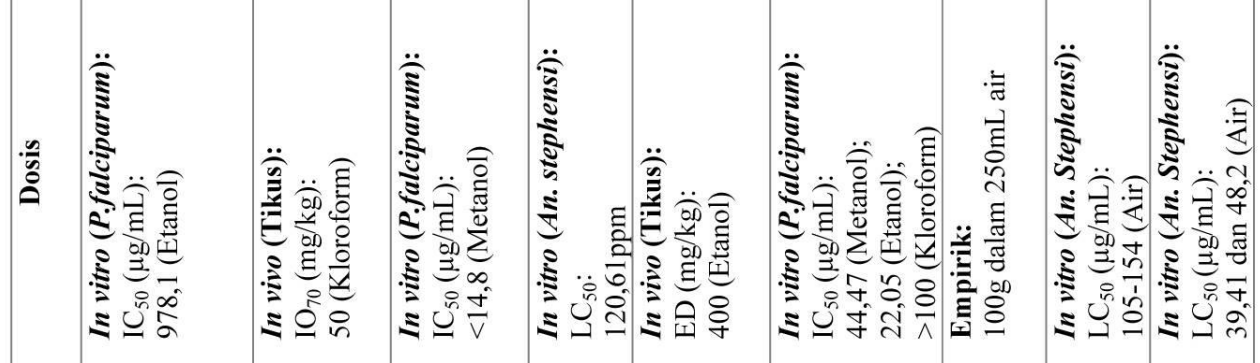

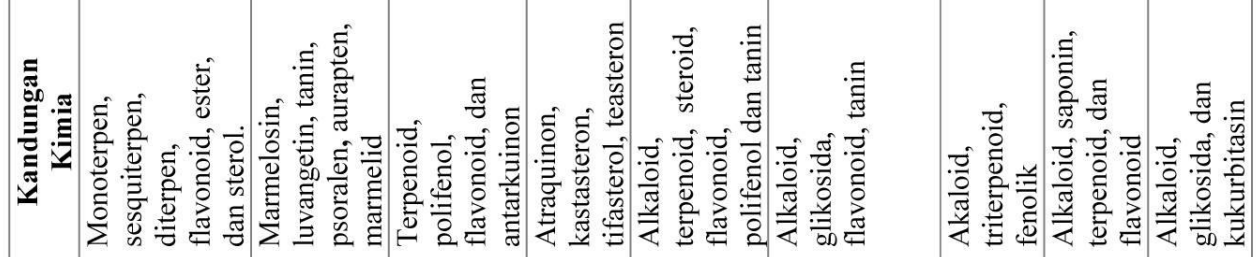
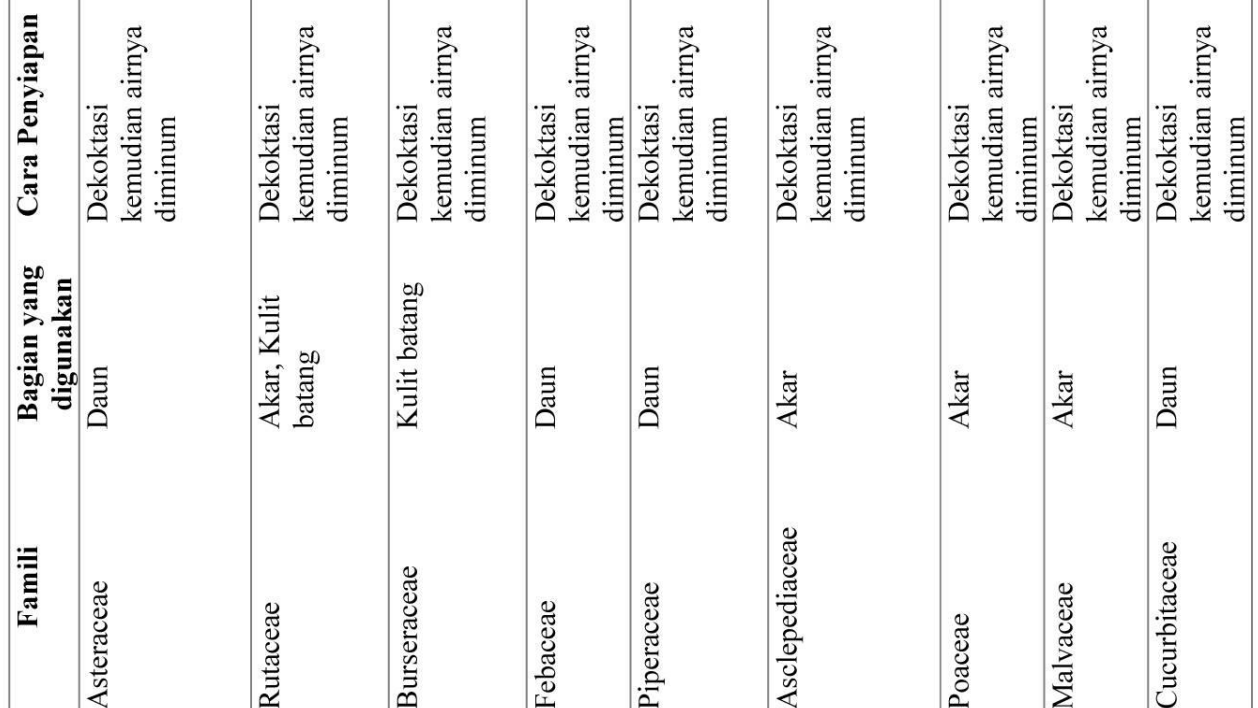

总

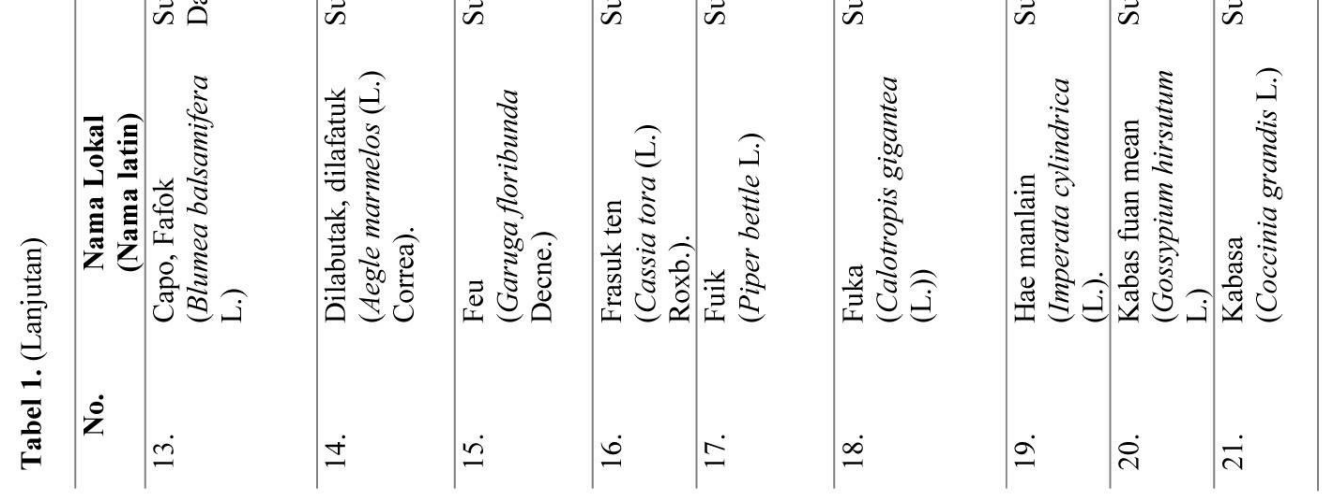


Tanaman Berkhasiat ... (Farah M., et al.)

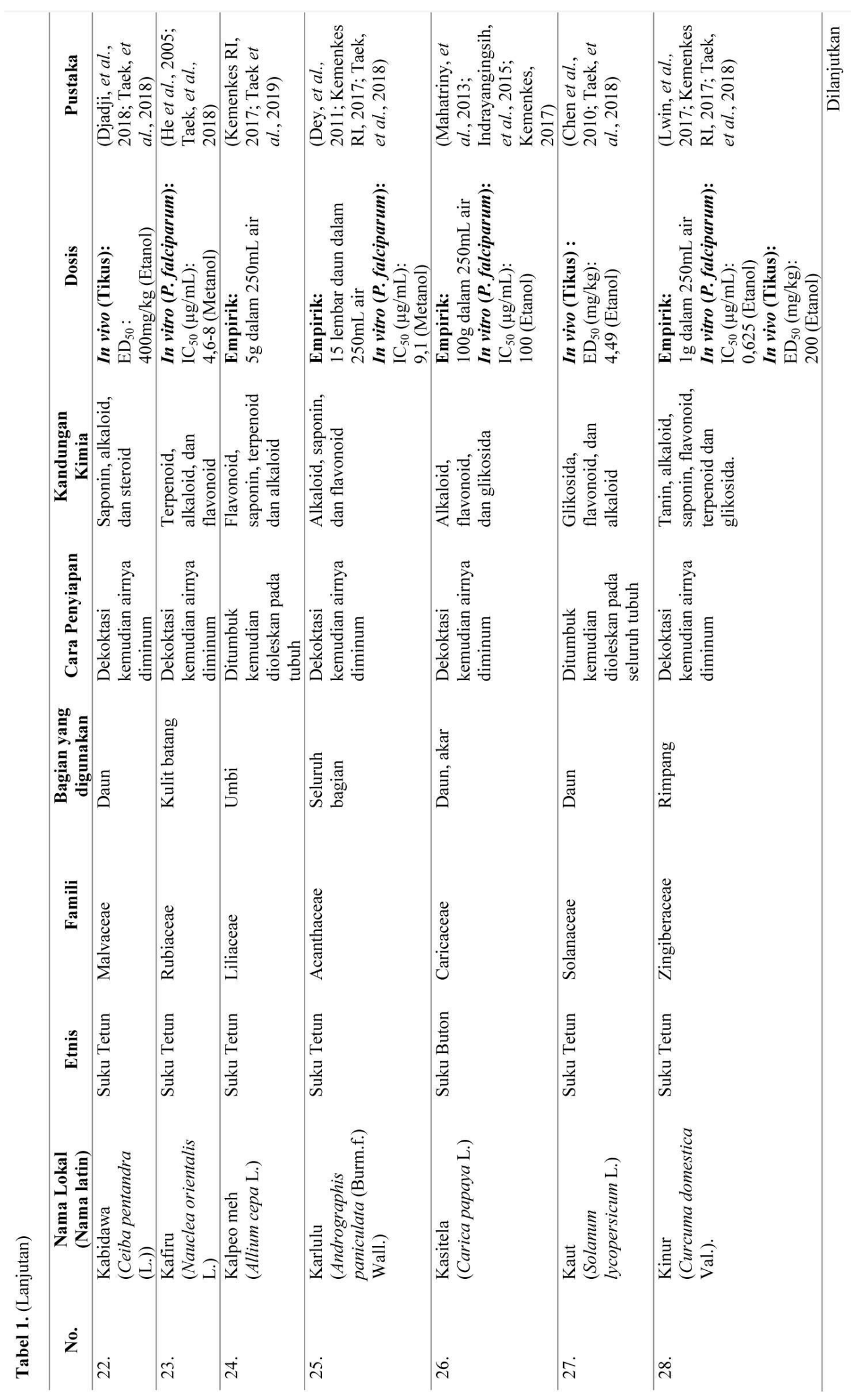




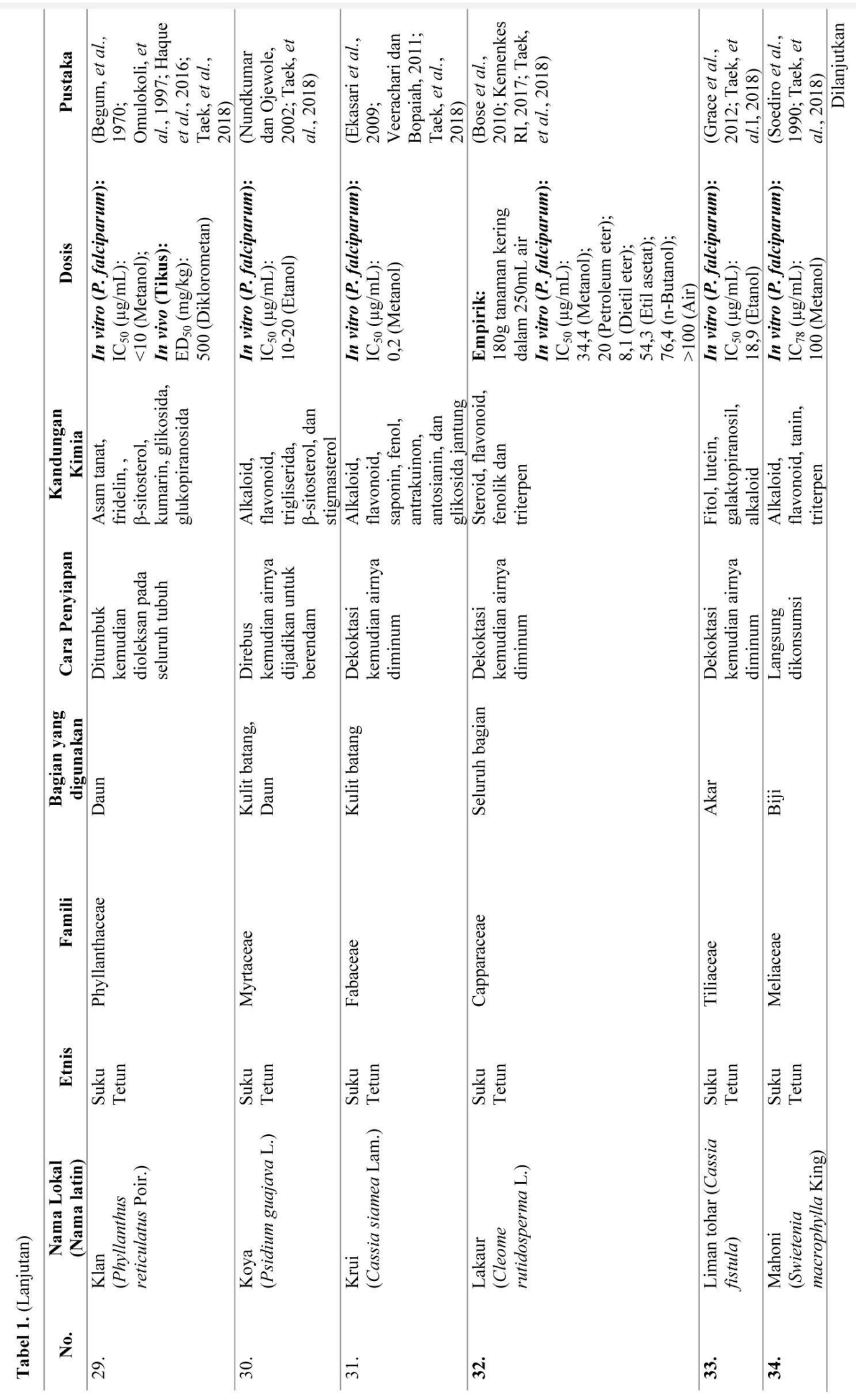


Tanaman Berkhasiat ... (Farah M., et al.)

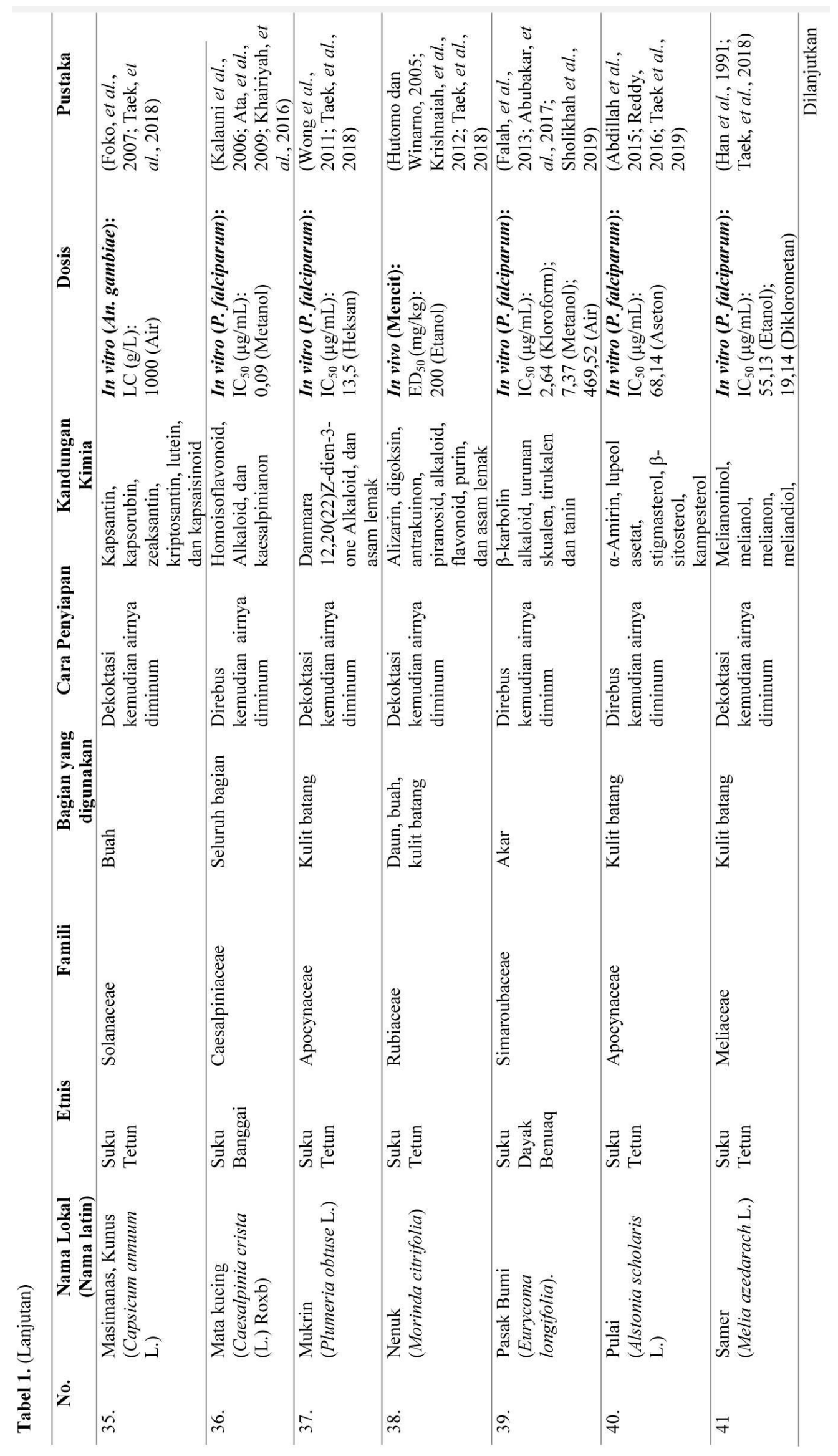




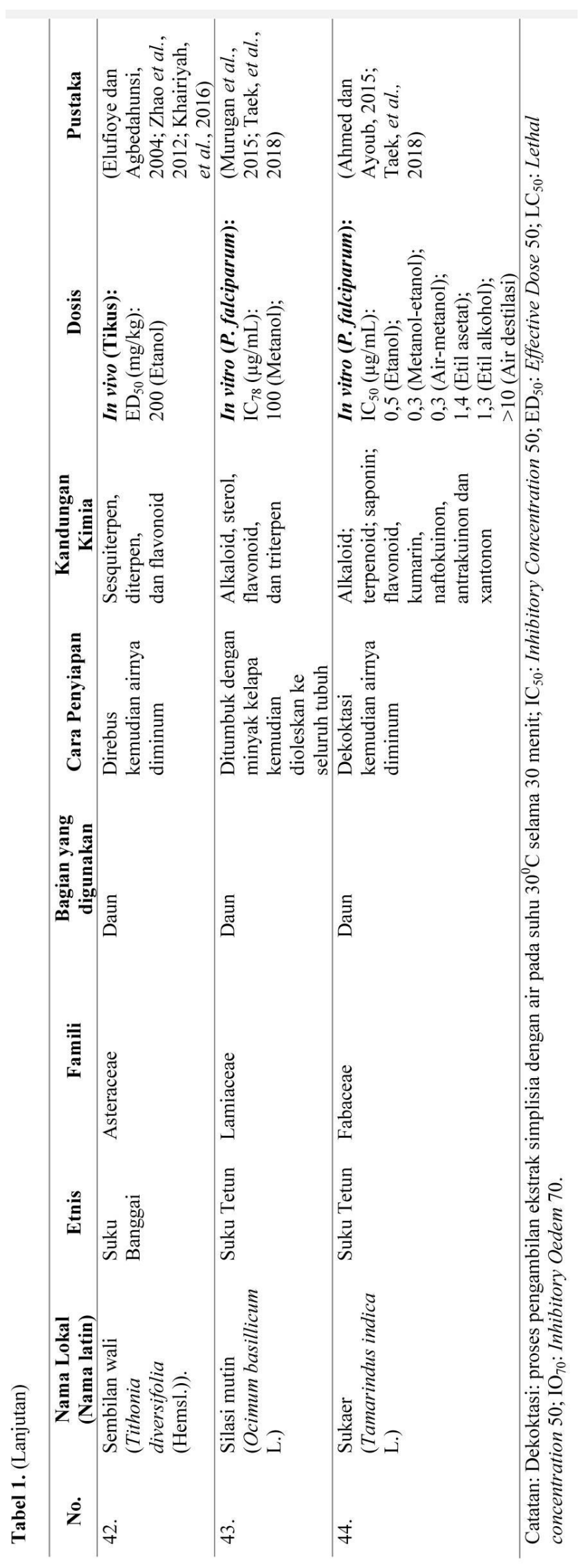


Selain in vitro, pengujian aktivitas antimalaria ditentukan berdasarkan Effective Dose $\left(\mathrm{ED}_{50}\right)$ pada uji In vivo yaitu dosis yang diperlukan untuk mencapai 50\% dari respons yang diinginkan pada $50 \%$ populasi dimana semakin kecil nilai $\mathrm{ED}_{50}$ maka semakin besar efektivitas yang diharapkan. Terdapat 12 tanaman yang telah diuji secara In vivo dan terlihat tanaman yang menunjukan nilai $\mathrm{ED}_{50}$ terkecil yaitu Tithonia diversifolia (Hemsl.), ED $\mathrm{ED}_{50} 200$ $\mathrm{mg} / \mathrm{Kg}$, dimana dosis tersebut menunjukkan peningkatan yang tajam dalam aktivitas kemosupresi infeksi malaria. Tithonia diversifolia (Hemsl.) diketahui memiliki senyawa golongan seskuiterpen yaitu tagitinin $\mathrm{C}$ yang bekerja secara sitotoksik terhadap Plasmodium sp. Keseluruhan efektivitas dosis (Elufioye dan Agbedahunsi, 2004) dan konsentrasi inhibisi pada tanaman berhubungan dengan senyawa yang terkandung dalam tanaman tersebut (Goffin et al., 2002).

Senyawa umum dari tanamantanaman berefek anti malaria merupakan metabolit sekunder. Senyawa yang terkandung dalam tanaman-tanaman tersebut adalah senyawa golongan saponin, alkaloid, flavonoid, dan tanin. Senyawa tersebut memiliki mekanisme masingmasing dalam pengobatan. Mekanisme ekstrak tanaman yang mengandung alkaloid yaitu menekan pertumbuhan protozoa pada jaringan darah, pada ekstrak tanaman yang memiliki kandungan senyawa golongan flavonoid, saponin, dan tanin mempunyai mekanisme dalam penurunan jumlah leukosit yang tinggi, dan tanaman yang mengandung tanin dan steroid mempunyai mekanisme dalam menghambat pertumbuhan Plasmodium dengan menurunkan ekspresi TNF- $\alpha$ (Falah, et al., 2013). Tanaman yang diklaim sebagai tanaman dingin seperti Ficus callosa dan Ceiba pentandra umumnya memiliki kandungan air yang tinggi pada bagian yang digunakan untuk pengobatan malaria sehingga tanaman tersebut dapat bertindak sebagai penyerap panas yang baik. Di sisi lain, tanaman panas seperti Capsicum annuum, Piper betle dan Acorus calamus mengandung minyak esensial, yang memiliki rasa pedas di lidah, atau sensasi panas saat terkena ke kulit. Tanaman panas ini berperan meningkatkan suhu tubuh dan meningkatkan produksi keringat, sehingga suhu tubuh kembali normal seperti mekanisme antipiretik. Beberapa senyawa dalam minyak atsiri dari tanaman ini, misalnya Blumea balsamifera, yaitu monoterpenoid dikenal memiliki berbagai aktivitas farmakologis (Jawa La dan Kurnianta, 2019).

Adanya kandungan diterpen dan seskuiterpen pada bagian tanaman tersebut memberikan ekstrak Tithonia diversifolia (Hemsl.) dan Caesalpinia crista (L.) memiliki aktivitas yang baik.

\section{KESIMPULAN}

Indonesia kaya akan tumbuhantumbuhan dengan latar belakang budaya yang dapat menyembuhkan penyakit malaria. Aktivitas farmakologis tanaman berkaitan dengan antiplasmodial dan antipiretik sehingga dapat digunakan sebagai pengobatan malaria. Tanaman yang memiliki tingkat penghambatan terbaik dari 44 tanaman yang ditemukan yaitu Caesalpinia crista (L.) dengan nilai IC50 $0,09 \mu \mathrm{g} / \mathrm{mL}$ dan tanaman dengan efektifitas terbaik yaitu Tithonia diversifolia (Hemsl.) dengan nilai $\mathrm{ED}_{50} 200 \mathrm{mg} / \mathrm{Kg}$. diketahui adanya kandungan diterpen dan seskuiterpen pada bagian tanaman tersebut memberikan efektivitas antimalaria yang baik.

\section{UCAPAN TERIMA KASIH}

Penulis berterima kasih kepada Bapak dosen mata kuliah metodologi dan penelitian, Rizky Abdullah.

\section{REFERENSI}

Abdillah, S., Tambunan, R.M., Farida, Y., Sandhiutami, N.M.D., Dewi, R.M. (2015). Phytochemical screening and 
antimalarial activity of some plants traditionally used in Indonesia. Asian Pacific Journal of Tropical Medicine, 5(6): 454-457.

Abubakar, B.M., Salleh, F.M., Wagiran, A. (2017). Chemical composition of Eurycoma longifolia (Tongkat Ali) and the quality control of its herbal medicinal products. Journal of Applied Sciences, 17(7): 324-338.

Ahmed, A.O.E.E., Ayoub, A.M.H. (2015). Chemical Composition And Antimalarial Activity Of Extracts Of Sudanese Tamarindus indica L. (Fabaceae). The Pharma Innovation, 4(4): 90-93.

Arul, V., Miyazaki, S., Dhananjayan, R. (2004). Studies on the antiinflammatory, antipyretic and analgesic properties of the leaves of Aegle marmelos Corr. Journal of Ethnopharmacology. 2004; 96(1): 159-163.

Asmara, I.G.Y. (2018). Infeksi malaria Plasmodium knowlesi pada manusia infection of Plasmodium knowlesi malaria in human. Jurnal Penyakit Dalam Indonesia, 5(4): 109-120.

Ata, A., Gale, E.M., Samarasekera, R. (2009). Bioactive chemical constituents of Caesalpinia bonduc (Fabaceae). Phytochemistry Letters, 2(3): 106-109.

Auta, K.I., Ajayi, O.O., Andy, Y.B., Ikpa, T.F. (2013). The effect of ethanolic extract of Hyptis suaveolens in malaria. International Journal of Scientific \& Engineering Research, 4(6): 2244.

Begum, T., Rahman, S.M., Rashid, A.M. (1997). Phytochemical and biological investigations of Phyllanthus reticulatus. Dhaka University Journal of Pharmaceutical Sciences, 5(1-2): 21-23.

Bose, A. (2010). Studies on in vitro antiplasmodial activity of Cleome rutidosperma. Acta Poloniae
Pharmaceutica Drug Research, 67(3): 315-318.

Chen, Y., Li, S., Sun, F., Han, H., Zhang, X., Fan Y., et al. (2010). In vivo antimalarial activities of glycoalkaloids isolated from Solanaceae Plants. Pharmaceutical Biology, 48(9): 1018-1024.

Dey, A. (2011). Alstonia scholaris R.Br. (Apocynaceae): Phytochemistry and pharmacology: A concise review. Journal of Applied Pharmaceutical Science, 1(6): 51-57.

Djadji, A.T.L., Effo, K.E., Any-Grah-Aka, S., Kouakou, S.L., Irie-N'Guessan, G., Kouakou-Siranay, G. (2018). The onset of action of aqueous extracts of Ceiba pentandra (Malvaceae) and Pseudocedrela kotschyi (Meliaceae) plants with potential antipyretic activity on young rats and their interactions with anti malaria drugs (Artemisinin-based Combination). Journal Clinical And Experimental Pharmacology And Physiology, 8(6): 1-7.

Ekasari, W. (2009). Antimalarial activity of cassiarin a from the leaves of Cassia siamea. Heterocycles, 78(2): 18311836.

Elufioye, T.O., Agbedahunsi, J.M. (2004). Antimalarial activities of Tithonia diversifolia (Asteraceae) and Crossopteryx febrifuga (Rubiaceae) on mice in vivo. Journal of Ethnopharmacology, 93(1): 167-171.

Falah F., Sayektiningsih T., Noorcahyati N. (2013). Keragaman jenis dan pemanfaatan tumbuhan berkhasiat obat oleh masyarakat sekitar Hutan Lindung Gunung Beratus, Kalimantan Timur. Jurnal Penelitian Hutan Dan Konservasi Alam, 10(1): 1-18.

Foko, G.A.D., Tamesse, J.L., Messi, J. (2007). Insecticidal effects of Capsicum annuum on aquatic stages of Anopheles gambiae giles under laboratory conditions. Journal of 
Entomology, 4(1): 299-307.

Garavito, G., Rincon, J., Artega, L., Hata, Y., Bourdy, G., Gimenez, A., et al. (2006). Antimalarial activity of some Colombian medicinal plants. Journal of Ethnopharmacology, 107(1); 460462.

Goffin, E., Ziemons, De mol, P., De Madureira, M. D., Martins, A. P., Da Cunha, A. P., et al. (2002). In vitro antiplasmodial activity of Tithonia diversifolia and identification of its main active constituent: Tagitinin $\mathrm{C}$. Planta Medica, 68(1): 543-545.

Grace, M.H., Lategan, C., Graziose, R., Smith, P.J., Raskin, I., Lila, M.A. (2010). Antiplasmodial activity of the ethnobotanical plant Cassia fistula. Natural Product Community, 7(10): 1263-1266.

Han, J. (1991). Studies on the chemical constituents of Melia Azedarach L. Yao Xиe Xиe Bao Acta Pharmaceutica Sinica, 26(6):426-429.

He, Z.D., Ma, C.Y., Zhang, H.J., Tan, G.T., Tamez, P., Sydara, K. et al. (2005). Antimalarial constituents from Nauclea orientalis (L.). Chemistry \& Biodiversity, 2(1): 1378-1386.

Heinrich, M. 2005. Ethnobotany and natural products: the search for new molecules, new treatments of old diseases or a better understanding of indigenous cultures? Current Topics in Medicinal Chemistry, 3(1): 29-42.

Hutomo, R., Sutarno, Winarto W., Kusmardi. (2005). Uji antimalaria ekstrak buah morinda citrifolia dan aktivitas makrofag pada mencit (Mus musculus) setelah diinfeksi Plasmodium berghei. Biofarmasi, 3(2): 61-69.

Ihsan, Sunandar, Kasmawati, H.S. (2016). Studi etnomedisin obat tradisional lansau khas Suku Muna Provinsi Sulawesi Tenggara. Pharmauho: Jurnal Farmasi, Sains, dan Kesehatan. 2016; 2(1):1-5.
Ihwan, Rifa'I, M., Fitri, L.E. (2014). Uji anti plasmodium ekstrak batang Tinospora crispa terhadap Plasmodium falciparum galur 3D7 secara in vitro. Jurnal Kedokteran Brawijaya, 28(2): 91-96.

Indrayangingsih, W.O.I., Ibrahim, N., Anam, S. (2015). Studi etnofarmasi tumbuhan berkhasiat obat pada Suku Buton di Kecamatan Binongko, Kabupaten Wakatobi, Sulawesi Tenggara. Jurnal Farmasi Galenika (Galenika Journal of Pharmacy), 1(2): 1-5.

Jawa La, E.O., Kurnianta, P.D.M. (2019). Review artikel tradisional di Indonesia Sebagai alternatif pengobatan malaria. Acta Holostica Pharmaciana, 1(1): 33-43.

John, T., Windust, A., Jurgens, Mansor, S.M. (2011). Antimalarial alkaloids isolated from Annona squamosa. Phytopharmacology, 1(3): 49-53.

Junairiah, J. (2019). Isolation and identification of secondary metabolites of Black Betel (Piper betle L. Var Nigra). Jurnal Kimia Riset, 3(2): 1-5.

Kalauni, S.K., Awale, S., Tezuka, Y., Banskota, A.H., Linkn T.Z., Asih P.B.S., et al. (2006). Antimalarial activity of cassane- and norcassanetype diterpenes from Caesalpinia crista and their structure-activity relationship. Biological and Pharmaceutical Bulletin, 29(5): 10501052.

Kemenkes RI. (2017). Formularium Ramuan Obat Tradisional Indonesia. No.

HK.01.07/MENKES/187/2017World Agriculture. DOI: 10.1038/132817a0.

Kemenkes RI. (2016). Infodatin Malaria. Jakarta: Pusat Data dan Informasi Kementerian Kesehatan Republik Indonesia.

Kemenkes RI. (2016). Plasmodium knowlesi: distribusi, gambaran 
mikroskopis, gejala penderita dan vektor potensial. Jurnal Ekologi Kesehatan, 13(3): 201-209.

Khairiyah, N., Anam, S., Khumaidi, A. (2016). Studi etnofarmasi tumbuhan berkhasiat obat pada Suku Banggai di Kabupaten Banggai Laut, Provinsi Sulawesi Tengah. Jurnal Farmasi Galenika (E-Journal), 2(1): 1-8.

Kohler, I., Siems, K.J., Siems, K., Hernandez, M.A. (2002). In vitro antiplasmodial investigation of medicinal plants from El Salvador. Zeitschrift Für Naturforschung, 1(57c): 277-281.

Krishnaiah, A., Duduku, Y., Nithyanandam, Rajesh, A., Sarbatly, Rosalam. (2012). Phytochemical constituents and activities of Morinda citrifolia L. In: Venketeshwer (Ed.). PhytochemicalsA Global Perspective of Their Role In Nutrition And Health. Kuala Lumpur: InTech Publisher.

Kuswantoro, F. (2017). Traditional anti malaria plants species of Balikpapan Botanic Garden, East KalimantanIndonesia. Knowledge E Life Sciences, 1(2): 78-85.

Lusakibanza, M., Meisa, G., Tona, G., Kareme, S., Lukuka, A., Tits, M., et al. (2010). In vitro and in vivo antimalarial and cytotoxic activity of five plants used in congolese traditional medicine. Journal of Ethnopharmacology, 24(1): 1-6.

Lwin, K.M., Man, H.M., Myint, K.H. (2017). Evaluation of the antimalarial activity of Curcuma longa Linn. singly and in combination with Eupatorium odoratum Linn. Journal of Ayurvedic And Herbal Medicine, 3(1): 11-14.

Mahatriny, N.N., Payani, N.P.S., Oka, I.B.M., Astuti, K.W. (2013). Skrining fitokimia ekstrak etanol daun pepaya (Carica papaya L.) yang diperoleh dari daerah Ubud, Kabupaten Gianyar, Bali. Jurnal Farmasi
Udayana, 3(1): 1-8.

Maslachah, L., Sugihartuti, R. (2018). Potency Syzygium cumini L. as adjuvant therapy on mice model malaria. Iraqi Journal of Veterinary Sciences, 32(1): 73-80.

Mishra, K. Dash, A.P., Dey, N. (2011). Andrographolide: a novel antimalarial diterpene lactone compound from Andrographis paniculata and its interaction with curcumin and artesunate. Journal of Tropical Medicine, 1(1): 1-6.

Mohammed, S.I., Vishwakarma, K.S. Maheshwari, V.L. (2017). Evaluation of larvicidal activity of essential oil from leaves of Coccinia grandis against three mosquito species. Journal of Arthropod-Borne Diseases, 1(2): 226-235.

Muhsin, M.D.A., Haque, T., Akhter, T., Haq, M.E., Begum, R., Uddin, S.F. et al. (2016). Antimicrobial and analgesic activity of leaf extracts of Phyllanthus reticulatus Poir. (family Euphorbiaceae). Jahangirnagar University Journal of Biological Sciences, 5(1): 81-85,

Murningsih, T. (2005). Evaluation of the inhibitory activities of the extracts of indonesian traditional medicinal plants against Plasmodium Falciparum and Babesia gibsoni. Journal of Veterinary Medical Science, 67(8): 829-31.

Murugan, K., Aarthi, N., Kovendan, K., Panneerselvam, C., Chandramohan, B., Kumar, P. M., et al. (2015). Mosquitocidal and antiplasmodial activity of Senna occidentalis (Cassiae) and Ocimum basilicum (Lamiaceae) from Maruthamalai Hills against Anopheles stephensi and Plasmodium falciparum. Parasitology Research, 114(10): 3657-3664.

Ningsih, I.Y. (2016). Studi etnofarmasi penggunaan tumbuhan obat oleh Suku Tengger di Kabupaten Lumajang dan 
Malang, Jawa Timur. Pharmacy: Jurnal Farmasi Indonesia, 13(1): 1693-3591.

Nundkumar, N., Ojewole, J. A. (2002). Studies on the antiplasmodial properties of some south african medicinal plants used as antimalarial remedies in zulu folk medicine. Methods And Findings In Experimental And Clinical Pharmacology, 24(1): 397-401.

Omulokoli, E., Khan, B., Chhabra, S.C. (1997). Antiplasmodial activity of four Kenyan Medicinal Plants. Journal of Ethnopharmacology, 56 (2): 133-7.

Onyegbule, F.A., Bruce, S.O., Onyekwe, O.N., Onyealisi, O.L., Okoye, P.C. (2019). Evaluation of the in vivo antiplasmodial activity of ethanol leaf extract and fractions of Jatropha gossypifolia in Plasmodium berghei infected mice. Journal Medicinal Plants Research, 13(11): 269-279.

Patil, C.D., Porase, H.P., Salunkhe, R.B., Suryawanshi, R.K., Narkhade, C.P., Salunke, B.K., et al. (2014). Mosquito larvicidal potential of Gossypium hirsutum (Bt cotton) Leaves extracts against Aedes aegypti and Anopheles stephensi Larvae. Journal of Arthropod-Borne Diseases, 8(1): 9110.

Perawati, S. (2019). Ethnopharmacy study of Suku Anak Dalam (SAD) in Muara Kilis Village, Tengah Ilir, Tebo District, Jambi Province. Biospecies, 12(2): 35-41.

Reddy, D.S. (2016). Phytochemical analysis of active constituents of Alstonia scholaris and their cytotoxicity in vitro. International Journal of Pharmaceutical Sciences And Research, 7(8): 3262-73.

Rinidar, A., Isa, M., Armansyah, T. (2013). Nilai inhibition concentration $\left(\mathrm{IC}_{50}\right)$ ekstrak metanol Daun Sernai (Wedelia biflora) terhadap
Plasmodium falciparum yang diinkubasi selama 32 dan 72 Jam. Jurnal Medika Veterinaria, 7(1): 1-4.

Septiana, E., Umaroh, A., Gangga, E., Simanjuntak. (2017). Aktivitas penghambatan polimerisasi heme ekstrak Daun Sembung (Blumea balsamifera) sebagai antimalaria haem polymerization inhibitory activity of Blumea balsamifera leaves extract as antimalarial. Buletin Penelitian Tanaman Rempah Dan Obat, 28(1): 29-36.

Shalikhah, E.N., Wijayanti, M.A., Nurani, L.H., Mustofa. (2018). Aktivitas antiplasmodium dan sitotoksisitas isolat Akar Pasak Bumi (Eurycoma longifolia Jack) secara in vitro. Majalah Farmaseutik, 14(2): 54-62.

Soediro, I., Padmawinata, K., Wattimena, J.R., Rekita S. 1990. Study of the active antimalarial methanolic extract of Swietenia macrophylla King (Meliaceae). Acta Pharmaceutica Indonesia, 15(1): 1-13.

Somsak, V., Polwiang, N., Chachiyo, S. (2016). In vivo antimalarial activity of Annona muricata Leaf Extract in mice infected with Plasmodium berghei. Journal of Pathogens, 1(1): 1-5.

Sriwilaijaroen, N. (2010). Antiplasmodial effects of Brucea javanica (L.) Merr. and Eurycoma longifolia Jack extracts and their combination with chloroquine and quinine on Plasmodium falciparum in culture. Tropical Medicine and Health. 38(2): 61-68.

Statish, P.V.V., Kumari, D.S., Sunita, K. (2017). Antiplasmodial efficacy of calotropis gigantea (1.) against Plasmodium falciparum (3D7 Strain) and Plasmodium berghei (ANKA). Journal of Vector Borne Diseases, 54(1): 215-225.

Sulastri, L., Syamsudin, Simanjuntak, P. (2018). Karakterisasi senyawa penghambat polimerasi heme dari 
Batang Brotowali (Tinospora crispa (L.)). Bioproral Industri. 9(2): 79-86.

Taek, M.M. (2019). Ethnomedicine of Tetun Ethnic people in West Timor Indonesia: philosophy and practice in the treatment of malaria. Integrative Medicine Research, 8(3): 139-144.

Taek, M.M., Ew, B.P., Agil, M. (2018). Plants used in traditional medicine for treatment of malaria by Tetun Ethnic people in West Timor Indonesia. Asian Pacific Journal of Tropical Medicine, 11(11): 630-637.

Thakur, G. (2009). Momordica balsamina: A medicinal and neutraceutical plant for health care management. Current Pharmaceutical Biotechnology, 10(7): 667-682.

Tripathi, K. (2013). Essential of medical pharmacology (7th edition). New Delhi: Jaypee Brothers Medical Publisher.

Vats, S. (2018). Larvicidal activity and in vitro regulation of rotenoids from Cassia tora L. 3 Biotech, 8(13): 1-4.

Veerachari, U., Bopaiah, A.K. (2011). Preliminary phyto-chemical evaluation of the leaf extract of five Cassia Species. Journal of Chemical and Pharmaceutical Research, 3(5): 574-583.

Verma, V.N. (2013). The chemical study of calotropis. International Letters of Chemistry, Physics and Astronomy, 20(1): 11-13.
Vical, F. B., Grellier, P., Abdoulaye, A., Moussa, I., Ousmane, A., Berry, A., et al. (2006). In vitro and in vivo antiplasmodial activity of Momordica balsamina alone or in a traditional mixture. Chemotherapy, 52(1): 288292.

Widyawaruyanti, A., Devi, A.P., Fatria, N., Tumewu, L., Tantular, I.S., Hafid, A.F. (2014). In vitro antimalarial activity screening of several indonesian plants using hrp2 assay. International Journal of Pharmacy and Pharmaceutical Sciences, 6(6): 125-128.

Wong, S.K., Lim, Y.Y., Abdullah, N.R., Nordin, F.J. (2011). Antiproliferative and phytochemical analyses of leaf extracts of ten Apocynaceae species. Pharmacognosy Research, 3(2): 100 106.

World Health Organization (WHO). (2010). Guidelines for the treatment of malaria, 2nd Edition, WHO [Diakses pada 9 Mei 2020]. Tersedia dari: www.who.int.

World Health Organization (WHO). (2018). The world malaria report 2018, WHO [Diakses pada 9 Mei 2020]. Tersedia dari: www.who.int.

Zhao, G.J. (2012). Chemical constituents from Tithonia diversifolia and their chemotaxonomic significance. Biochemical Systematics and Ecology, 44(1): 250-254. 